\title{
Ukrainian Revolution of Dignity perceived from a Hegelian Perspective
}

\author{
Carsten Lier \\ BA Student of International Law, Institute of International Relations, \\ Taras Shevchenko National University of Kyiv \\ (Kyiv, Ukraine) \\ E-mail: carsten.lier98@gmail.com \\ Vadym Tytarenko \\ Ph.D. (Philosophy), Associate Professor, \\ Taras Shevchenko National University of Kyiv \\ (Kyiv, Ukraine) \\ E-mail: tytarenko.vadym@gmail.com \\ https://orcid.org/0000-0001-9251-8859
}

Lier, Carsten and Vadym Tytarenko (2020). Ukrainian Revolution of Dignity perceived from a Hegelian Perspective. Ukrainian Policymaker, Volume 6, 2020: 43-51. https://doi. org/10.29202/up/6/5

The political protest against the former decision of Yanukovych to reject the Association Agreement with the EU quickly evolved into mass mobilization against the corrupt socio-political structures that dominated Ukraine throughout its post-Soviet history. For that reason, it became evident that Euromaidan showcased a historical process marking a transition towards the formation of a "prototype" civil society that has been virtually non-existent in the country's post-Soviet era. In this article, in order to understand these underpinning historical dynamics, the event will be analysed through Hegel's framework of the state and the historical dialectic. In this context, authors argue that the "Revolution of Dignity" is a historical turning point towards the formation of a new civil consciousness and self-identification with the Ukrainian state through laying down foundations for the creation of a liberal democratic state postMaidan. As an important step of this analysis, Hegel's and Marx's concepts of history were examined. Firstly, Hegel's view on the state made it possible to argue that the Ukrainian post-soviet state resulted in the alienation of citizens from the state. This idea was furthered by using Hegel's historical dialectic to allow for an interpretation of Euromaidan as an antithesis to post-Soviet era. Finally, the focus was shifted towards the limitations of applying Hegel's theoretical framework to the $21^{\text {st }}$ century events.

Keywords: Ukraine, Revolution of Dignity, Euromaidan, Hegel, Marx, history, state, revolution

Received: March 26, 2020; accepted: April 23, 2020

(C) Lier, Carsten, 2020

(C) Tytarenko, Vadym, 2020 


\section{Introduction}

The Revolution of Dignity was, at the same time, tragic and glorious moment of recent Ukrainian history. It is tragic because of numerous human victims in civilians ("Heavenly Hundred") as a result of force confrontation between people and police troops. The number of victims is still growing because later, the Revolution grew into a military conflict in Donbas, which remains escalated for five years already with no perspective for resolution within the nearest observable time. It was glorious because of a set of broad political transformations that succeeded the revolutionary events, probably the most profound since the time Ukraine got its Independence in 1991.

The Revolution of Dignity, also known as "Euromaidan," was not the first uprising of Ukrainian people since the collapse of the Soviet Union. The first attempt to overcome the soviet, totalitarian, and suppressive way of ruling the country was made in 2004 by more than half of the Ukraine population led by Victor Yushenko. The set of protests all over the country between November and December 2004 was named the "Orange Revolution" and widely supported by the majority in Ukraine. As a result of those first transformational steps a lot of positive and progressive amendments were made to Ukrainian legislation that defined the European course of Ukraine. That first uprising never involved any armed confrontation between the parties, which essentially differs it from the second wave - Revolution of Dignity.

In both cases, the Russian Federation's geopolitical interests were infringed that caused a set of political actions against Ukraine (gas prices war, diplomatic crisis, etc.) in 2005 and the escalation of a military conflict in 2014 (the annex of Crimea and separation of a part of Donetsk and Luhansk regions ruled by the terroristic organizations DNR and LNR). The partly-successful reforms managed by the pro-European Ukrainian leaders between 2004 and 2010, the internal political instability of Ukraine and political, economic, and diplomatic counteraction from the side of the Russian Federation lead to a political reverse and coming Viktor Yanukovych into power again in February 2010.

Since 2010 the European course of Ukraine became rather nominal then practically real. The internal and international policy of Ukraine was under the substantial influence of Russia, and, as a consequence, most of the democratic changes and steps made to leave the totalitarianism behind were suspended. Under the mask of the democracy, Yanukovych was hiding his real totalitarian "face," which could be seen from the policy provided by his political party and methods that were used to control the fields of economy and politics in Ukraine.

The protests that eventually turned into Euromaidan started as a small political action that took place on the European Square and Independence Square in Kyiv after Yanukovych's refusal to sign the Ukraine-EU Association Agreement in November 2013. People peacefully demanded to preserve the European Course of Ukraine. As the answer to that demand, the special police troops attacked the group of student protesters in order to intimidate people and stop the protest. This violent action became a final straw that made Ukrainian people rise again. The number of protesters was growing fast after that first attack and reached 1 million people, who demanded changes to the constitution, the Ukraine-EU Association Agreement, and Yanukovych resignation. The severe violence escalation started after Yanukovych regime started to suppress the protesters both by introducing anti-protest laws and using police to 
attack the protesters. On February 21, 2014, Yanykovych signed the capitulation agreement with opposition, and soon after it, he exiled to Russian Federation. As a result of a violent escalation during the Revolution of Dignity, more than 100 people were killed and more than 1100 injured.

In the complicated and challenging historical situations, it seems to be beneficial to look for the answers in the history of Philosophy, which proved itself as a reliable crisis counselor. One of the best examples of scrutinized philosophical consideration of revolutionary changes in the societies and their historical role was done by prominent German $19^{\text {th }}$ century philosopher Georg Wilhelm Friedrich Hegel (1770-1831). Another philosophical theory that attempted to clarify the same issues was developed by Hegel's prominent follower Karl Marx. We will try to examine the phenomenon of Ukrainian democratic revolutions through the lenses of Hegelian understanding of history and see if they could be explained from such perspective and what consequences we should expect, respectively.

Written in 1820 G.W.F Hegel's Philosophy of History marked a notion of history that is dialectical, resulting in an overall view that conceives the movement of history in progressive terms towards greater Human freedom. Such interpretation has given many grounds of critique and influence on later thinkers. Most notably, Hegel's influence on Karl Marx had a profound impact on his understanding of History that adopted Hegel's progressive view of history to arrive at his theory of social change. In this context, Hegel and Marx both envisage a progressive dialectical pattern towards greater Human freedom but present a magnitude of fundamental differences in their theories on History. Within this framework, authors claim that Hegel's understanding of historical change needs to be understood as contradictions between ideas that result in greater human freedom, whereas Marx inverts this theory to conceptualize history as material tensions that shape progressive human freedom. This thesis will be supported by, first, establishing a comparative frame through highlighting the crucial distinction between Hegel's absolute idealism and Marx's historical materialism, in connection to their views on History and Freedom. Building on this distinction, it will be argued that while both use a progressive dialectical method, they fundamentally differ in their content of historical epochs. Subsequently, this idea will be furthered by examining their divergence in the choice of agency for bringing progressive change. Finally, the focus will shift towards the argument that both anticipate a distinct point of historical culmination but contradict each other in their definition of absolute freedom.

\section{Hegel's and Marx's understanding of history and historical change}

In order to fully comprehend the Hegel-Marx distinction in their particular understandings of History, it is important to place these two thinkers in their respective philosophical traditions. Here, it is crucial to bring forth the debate of idealism and materialism as two distinct ways to approach the question of interpreting history. Most notably, Hegel is known to be living in the Prussian state during the time of German idealism (Redding, 2015). However, it is important to point out that Hegel did not take an idealistic stance in the moral sense that he expects well of the world in general but "in a deeper philosophical sense that reality is ultimately thought or idea" (Williams, 2008: 558). In this regard, from the standpoint of Hegelian idealism, it is the idea in the abstract which impacts the environment and drives further development (Mohsin, 2014: 4). For him, ideas serve as the mechanism for historical progress, in the sense that it involves the development and realization of Reason (Sayers, 2010: 3). This implies that ideas 
create objects and are the roots and build of the world. Therefore, the fundamental characteristic of Hegel's absolute idealism is that it places ideas before matter resulting in a view that ideas are the foundation for conceptualizing historical development (Mohsin, 2014: 4). Contrarily, Marx's historical materialism rejects this account of idealism and inverts it. In this sense, Marx claims that "it is not the consciousness of men that determines their existence but their social existence that determines their consciousness" (Marx, 1859: 4). Here, it becomes evident that for Marx, it is not the ideas that drive history, but rather the material conditions that define man's existing reality and act as the agitators for its evolution and progress (Mohsin, 2014: 8). Thus, Marx believes, unlike Hegel, that human beings come before ideas and that the world is ultimately matter in origin (Williams,2008: 558). Therefore, Marx's materialism adopts Hegel's basic progressive dialectical methodology but views History not as a contradiction between unreason and reason but instead between social-economic production systems (Soultani, 2014: 9). Hence, it becomes clear that Marx`s historical materialism diverts fundamentally from Hegel's idealism, which is crucial to further analyse the dimensions of how these two thinkers differ in their understandings of history.

Building on the aforementioned distinction, it became evident that there is a fundamental contrast between these two schools of thought. However, to understand Hegel's and Marx's view of history more precisely, it is important to unpack their views of historical stages. As already noted, Hegel establishes a model in his Philosophy of History that conceives history as the unfolding of Reason, which means that mistaken modes of self-understanding transfer into new formations of self-understanding, resulting in a new manifestation of the consciousness of freedom (Hutchings, 2014: 22). In this understanding, Hegel contends that for him, "History of the world is none other than the progress of the consciousness of Freedom" (Hegel, 2001: 33). At the core of this progressive development is Hegel's dialectic, which acts as a method of an idea (Thesis) being contradicted by a counter idea (Antithesis), creating an absolute idea of consciousness of freedom (Wisdom, 1940: 243). Here, Hegel conceptualizes four so-called "Realms" - the Oriental, Greek, Roman, and Germanic — that have contradicted each other throughout history to attain pure Reason and Freedom (Sayers, 2010: 4). Here, Hegel views the cunning of Reason through different layers of knowing and being (Mccarney, 2000: 135). As the fundamental motif is freedom, it is the progress from the ancient world where at best, some people are free to modernity where freedom in Hegel's view is known to be a basic right of all human individuals (Mccarney, 2000: 136). In this context, it is a process from a state of being where society is not one with universal Reason, to a state of the Germanic Realm in which the "state reveals the image and actuality of Reason" (Hegel, 1991: 380) and absolute Freedom.

This is not to say that Marx completely opposes this progressive dialectical pattern. In fact, he agrees with Hegel as seeing History as rational and law-like, but, as it was argued previously, he inverted it to arrive at his philosophy of historical materialism. In this regard, it should be pointed out that Marx`s view on History follows a similar pattern, but they crucially differ in their content of historical stages (Sayers, 2010: 5). This suggests that Marx acknowledges Hegel's progressive process of historical development, but unlike him, he does not locate historical stages in universal reason but in a dialectic of social material activities (Soultani, 2014: 9). This view is explicitly made clear in his Economic Manuscripts in which he declares that "with me, on the contrary, the ideal is nothing else than the material world reflected by the human mind, and translated into forms of thought" (Marx, 1873: 14). Here, the material realities of individuals created distinct historical stages that subsequently produced classes of 
property owners and workers. However, although Marx stresses five historical stages, only the three main ones are important for this analysis.

As seen under Feudalism, the land was owned by the aristocracy who exploited the peasantry, creating eventually a capitalist class of factory owners (bourgeoisie) and workers (proletariat). In this context, Marx insists that these new productive forces will eventually cause overproduction and lead to the collapse of the entire capitalist system through a proletariat insurgency (Yadav,2018: 3). Therefore, it is only under communism that the historical class struggle will cease, and individuals will attain complete freedom. Thus, the historical stages for Marx are defined by the continuous class struggle that emerged as a consequence of the material reality, underpinning his understanding that "the history of all hitherto existing society is the history of class struggles" (Marx, 1848: 14). Through these claims, it is evident that Marx's stages of history emerge from the mass of productive forces, not from the unfolding of Reason and self-consciousness, which ultimately supports the view that Marx`s progressive history needs to be grasped as material tensions that shape human freedom.

Expanding on the aforementioned distinction, there is one more fundamental difference within this argumentation that should be highlighted. As it was noted, historical stages for Hegel are defined by the unfolding of Reason. This encompasses that the cunning of Reason is a self-mediating process in which humans are only receptors of its activity, and thereby man has no conscious of the outcome of his actions (Williams, 2008: 199). Here, it should be mentioned that Reason is the essence of the absolute spirit (Geist), which means that "spirit is in and for itself reason" (Hegel, 1991: 372). In this regard, the spirit appears to be not "only substance but rather an active subject as well" (Hegel, 2001: 7). Therefore, the spirit is for Hegel, the main agent that guides the unfolding of history (Williams, 2008: 199). Human individuals, on the other hand, are the objects as they are the instruments of the spirit to move towards a new consciousness, presenting a process of collective learning to guide all world events towards a realized end (Hutchings, 2014: 5). Similarly, Marx agrees that there is agency during historical development but rejects Hegel's theological standpoint (Williams, 2008: 199). Instead, as it was argued, he places emphasis on the forces of production. For Marx, agents are the social classes that historically created tensions between the free and not free people. He sees the main agency in the proletariat, which will guide the task of world history towards a realized end (Williams, 2008: 199). This implies that once this proletariat class becomes politically aware, they will rise up and overthrow the bourgeoisie through the catalyst of a revolution. Thus, it can be argued that Marx`s choice of agency is mainly devoted to the way in which the working class can most constructively shape history in the desired direction (Williams, 2008: 199). Furthermore, since the social classes are the principle agent for Marx, it becomes clear that there is an opportunity for the human individual to consciously intervene and shape the course of history (Williams, 2008: 199), subsequently undermining the implication that their choice of agency is different in its emphasis.

Insofar, through the analysis of historical stages and agency, it became evident that for both thinkers, history has a purpose, as there is a specific point of culmination in which absolute freedom is attained. Here, it can be argued then that both Hegel and Marx employ a Teleological Notion of history, despite their visions of the end of history contradicting each other. In this regard, it was pointed out that Hegel sees the end in the Germanic Realm, in which the condition of full human freedom and self-consciousness has reached its realization in the "final aim of the world" (Hegel, 2001: 54). This implies that for Hegel, the Germanic stage is embodied in the Prussian state that constituted a modern bourgeois liberal society 
(Sayers, 2010: 4). However, there are certain limitations in this view that have to be taken into consideration. In this context, it is not necessarily an end of history in itself but rather an end that is dynamic. Since Hegel lived in the Prussian state, he referred to himself as a child of his own time, which signifies that he only saw an end of history in his own temporary perception (Hutchings, 2014: 21). Likewise, Marx`s end to history is also dynamic in the sense that there is a high point reached, but this point is a continuous process (Williams, 2008: 198). However, the main difference in their end of history is to be found in their contradiction of absolute freedom; whereas Hegel sees the realization of freedom within the bourgeois society, Marx contradicts and criticizes this viewpoint by arguing that freedom can only be attained through communism where the proletariat will finally return to himself as a social being (Williams, 2008: 206). Therefore, it is clear that despite both envisaging an ultimate purpose in history, they fundamentally divert in their definition of what absolute freedom truly means.

\section{A Hegelian perspective on Ukraine's "Revolution of Dignity"}

To understand the complexity of Euromaidan as a historical process, it is worth assessing the socio-political structures in post-Soviet Ukraine. Hegel's political theory on the state makes substantive claims on the function of the state in relation to the individual's self-consciousness (Hutchings, 2012: 4). For Hegel (1991: 275), the state functions as a mechanism of ethical behaviour and is thus the highest embodiment of self-consciousness. This view implies that the state is the ultimate reflection of the consciousness of civil society. Where the state fails to implement the aforementioned rule, Hegel would classify the state as a "bad state [..., which] merely exists" (Avineri, 1972: 182). Under Hegel's conception of a bad state, it "cannot reach its full ethical potential without [...] a robust civil society" (Searle, 2015: 8). In regards to postSoviet Ukraine, the civil consciousness and the state have been alienated from each other since the state utilized the "monopolization of the public sphere" (Searle, 2015: 8) for private ends. During Yanukovych's presidency, his criminal syndicate reached almost all components of the Ukrainian state and life by allegedly embezzling almost 100 billion dollars and upholding a mafia-like social structure (Faulconbridge et al., 2014). In Hegel's view, this act resulted in the self-consciousness of the people not finding its expression in the post-Soviet Ukrainian state. Therefore, the Ukrainian civil society's self-consciousness could not emerge from the structures built by the governing elite's criminal setting of the functioning of the society. This, then, further aggravated the dehumanisation of the collective moral consciousness (Searle, 2015: 9). The aforementioned served as a prerequisite to the "Revolution of Dignity", where "the possibility and necessity of overall social change" (Avineri, 1972: 185) furthers the need for political development. To further evaluate Euromaidan as a consequence of historical developments, Hegel allows exploring the issue through his dialectical method of how historical change takes place.

Having explored post-Soviet Ukraine through the lens of Hegel's notion of state, it is evident that Euromaidan can be interpreted as a logical progression in Ukraine's development. In Philosophy of History, Hegel argues that the "History of the world is none other than the progress of the consciousness of Freedom" (Hegel, 2001: 33). In this understanding, Hegel establishes a model that conceptualizes history as a progressive historical development, as mistaken modes of self-understanding shift towards a new form of self-understanding in terms of consciousness of freedom (Hutchings, 2014: 22). Hegel's interpretation of history is, therefore, towards greater freedom, achieved through the means of an idea (Thesis) being 
challenged by a counter-idea (Antithesis), subsequently producing a new idea (Synthesis) (Chalala, 2013). At the core of the development towards greater freedom, humans are at the center of the nation in order to fulfil the move towards a new consciousness (Hegel, 1991: $375)$, presenting a process of collective learning, in which socially and historically embedded self-consciousness comes to realize itself (Hutchings, 2014: 5). Therefore, a Hegelian analysis through the lenses of his historical dialectic would argue that the "Revolution of Dignity" can be regarded as the "antithesis" to the corrupt socio-political structures that were evident in all spheres of Ukrainian civil life prior to the Revolution (Shveda and Park, 2016: 86). In this context, Euromaidan challenged the post-Soviet consciousness deeply embedded within Ukrainian civil society and replaced it with a freedom-loving consciousness that portrays the coming of age of Western values of democracy and freedom (Searle, 2015: 4). Therefore, in viewing Euromaidan as the antithesis to Ukraine's post-soviet era, Euromaidan resulted in a Hegelian "synthesis" that laid the foundations for a future liberal democracy and new civil consciousness.

However, using Hegel's methodology to understand contemporary events presents its limitations and problems. First and foremost, Hegel was opposed to a change in perception and self-consciousness through revolutionary means (Tytarenko, 2019). In this case, an application of a different, later thinker might be able to account for the revolutionary aspect of this analysis. Furthermore, Hegel was a supporter of a constitutional monarchy (Hutchings, 2014: 19), not contemporary political structures and their interpretations of freedom, such as liberal democracy. Lastly, Hegel noted that he was a child of his own time, which impairs the analysis by having to set it back in time to his perception of the Prussian state, which carries a different mode of governance than argued here.

\section{Conclusions}

The author's attempt to analyse recent Ukrainian revolutionary events through the lenses of the Hegelian philosophy of history and dialectical methodology has shown that it is possible to draw some important conclusions. The escalation of the Revolution of Dignity (2014) and the preceding Orange Revolution (2004) reflected the essential social tension that had been increasing gradually and reached its culminating point. According to Hegel, after the Ukrainian people finally became aware ("enlightenent") about the real motives of the Yanukovich regime, a "controversy" (social tension) had turned to "contradiction" (culmination) and eventually to revolution. Such a scenario, in Hegel's opinion, works for any revolution unless it is just a secret plan of any minority to take over the power in the state. Russian Federation has been tending to use the latter explanation for Revolutions in Ukraine since 2004. However, numerous political and cultural studies have shown that Ukrainian revolutions have essential social and political grounds.

Providing a substantial explanation of reasons why revolutions take place and their inevitability under particular circumstances, Hegel, at the same time, introduces his negative attitude to revolutions by highlighting that revolutions appear to be the result of a specific kind of ignorance concerning the ultimate rational principles of reality. Any revolution, in his opinion, violates his famous rule that "The rational is real, and the real is rational." (Hegel, 1991:20) Such ignorance, according to Hegel, is widely spread among young people who are guided by the socalled "The law of the heart" - the state of being too emotional and ready to change the existing order to a better one. Hegel claims that this inevitably leads to "The frenzy of self-conceit" -.the 
state of being sure that one's particular vision of necessary changes is the best and urgently needs implementation. Those two states are the representation of "moral sentimentalism," which is typical for young people. However, Hegel thinks that revolutions, in fact, do nothing more than destabilization of a present political and state order, which is already perfect on its own. The problem is that young revolutionaries are not able to understand its perfection until they grow old enough. The main threat, which revolutions bring with them, is the threat of anarchy. The restoration of an appropriate state order may take a long time and effort without any guarantees. In the case of success, the revolutionaries feel the "absolute freedom" which in Hegel's terms leads to "terror" — the aggressive war against the enemies of revolution and voluntarism. As a historical example, Hegel used the French Revolution of 1789. However, it is clearly seen that any political revolution can be described using the same scheme, and Ukrainian revolutions are not the exception. In the course of the Revolution of Dignity, all mentioned stages could be seen, and the restoration of the state order after the revolution took significant time (paralyzed police and other state services, uncontrolled weapons, vandalism, assaults, etc.) The main Hegel's warning concerning revolutions as the method of change was that the result has to be worth the price state pays for it. The Revolution of Dignity lead to substantial positive democratic changes in Ukraine. However, the people still have to deal with the drawbacks of a revolutionary path (economic crisis, separatism, terrorism, political instability, etc.)

Hegel's prominent follower Karl Marx had his own warnings concerning the possible results of revolutions. Through the analysis of Hegel's and Marx's understanding of history, it becomes evident that Marx has adopted fundamental characteristics of Hegel's progressive notion of history. However, through the frame of the thinkers' philosophical traditions, it has also been assessed that there are specific differences that have to be taken into account to understand that Hegel's notion of history has to be grasped as ideas that shape Human freedom whereas for Marx this process is defined by the material tensions. This has particularly been supported through the discussion of Hegel's and Marx's conceptualizations of historical stages and the agency to bring Human freedom towards a realized end. Marx warned that revolution, whose aim is just to change the rulers (political revolution) - is a fake. Nothing ever changed after such revolutions. In order to bring real changes, the revolution must change society - the social order. In Ukraine, particular social change was inevitable in order to leave the totalitarianism behind and join the European community. The Revolution of Dignity has definitely started this social change.

Despite the aforementioned limitations in applying Hegel to modern events such as the Revolution of Dignity, there are certain positives from utilising his methods. Through using his theoretical framework in analysing Euromaidan, it allows to set the event in the historical timeline of the development of Ukrainian desire for a liberal democratic state and the development of the citizen's self-consciousness of freedom. The further developments in Ukraine post-Maidan will be the first and foremost evaluation of the analysis and claims made in this paper.

\section{[D] References}

Avineri, Shlomo (1972) The State - the Consciousness of Freedom, in Hegel's Theory of the Modern State, (London: Cambridge University Press), 176-193.

Chalala, Elie (2013) "The Arab Spring Hasn't Bloomed Yet...But Hegel's "Philosophy of History” Says it Will!”, Al Jadid, 2013, accessed at https:/www.aljadid.com/content/ 
arab-spring-hasn $\%$ E2\%80\%99t-bloomed-yet $\%$ E2\%80\%A6-hegel $\%$ E2\%80\%99s\%E2\%80\%9Cphilosophy-history\%E2\%80\%9D-says-it-will-0, 24 April 2020.

Faulconbridge, G., Debrowska, A. and Grey, S. (2014) Toppled 'mafia' president cost Ukraine up to $\$ 100$ billion, prosecutor says. Reuters, 30 April, accessed at https://www.reuters. com/article/us-ukraine-crisis-yanukovich/toppled-mafia-president-cost-ukraine-up-to100-billion-prosecutor-says-idUSBREA3T0K820140430, 26, April 2020.

Hegel, G.W.F (1991) Elements of the Philosophy of Right. Cambridge: Cambridge University Press.

Hegel, G.W.F (2001) The Phenomenology of Mind. London.

Hegel, G.W.F (2001) The Philosophy of History. Kitchener: Batoche Books.

Hutchings, Kimberly (2012) Hard Work: Hegel and the Meaning of the State in his Philosophy of Right. in Brooks, Thom (ed) Hegel's Philosophy of Right. Oxford:Blackwell, 124142.

Hutchings, Kimberly (2014) Hegel, Georg Wilhelm Friedrich (1770-1831). The Encyclopedia of Political Thought, September 2014, accessed at https://onlinelibrary.wiley.com/doi/ full/10.1002/9781118474396.wbept0457, 23 April 2020.

Marx, Karl (1859) A Contribution to the Critique of Political Economy, $2^{\text {nd }}$ edition. Moscow: Progress Publishers.

Marx, Karl (1873) Capital: A Critique of Political Economy, $4^{\text {th }}$ edition. Moscow: Progress Publishers.

Marx, Karl and Engels, Frederick (1848) The Manifesto of the Communist Party, $3^{\text {rd }}$ edition. Moscow: Progress Publishers.

McCarney, Joe (2000) Hegel on History, $1^{\text {st }}$ edition. London: Routledge.

Mohsin, Mahboob (2014) Idealism and Materialism: Development and Comparative Analysis. Lahore University of Management Sciences.

Redding, Paul (2015) Georg Wilhelm Friedrich Hegel. Stanford Encyclopedia of Philosophy, accessed at https://plato.stanford.edu/entries/hegel/\#LifWorInf, 14 May 2020.

Sayers, Sean (2010) Marx, Hegel, and the historical approach. Beijing lectures: Marx's Philosophy of History.

Searle, T. Joshua (2015) No Revolution without Reformation: A Hegelian Reading of Maidan as a Civil and Religious Reformation, in van der Laarse, R., Cherenkov M.N., Proshak V.V. and Mykhalchuk T. (eds.) Religion, State, Society, and Identity in Transition Ukraine. Oisterwijk: Wolf Legal Publishers, 299-319.

Shveda, Yuriy and Ho Park, Joung (2016) Ukraine's revolution of dignity: The dynamics of Euromaidan. Journal of Eurasian Studies 7(1): 85-91.

Soultani, Parisa (2014) The Arab Spring from Hegelian and Marxist Perspectives. Journal of Political Science:1-14.

Tytarenko, Vadym (2019) War and Peace in Kant's and Hegel's Consideration, Philosophy and Cosmology, Volume 22, 2019: 181-187. https://doi.org/10.29202/phil-cosm/22/17

Williams, Howard (2000) The End of History in Hegel and Marx, in Burns, Tony and Fraser Ian (eds.) The Hegel-Marx connection. UK:Palgrave Macmillan, 198-217.

Wisdom J.O. (1940) Hegel's Dialectic in Historical Philosophy. $19^{\text {th }}$ Century Philosophy 15(59):243-268.

Yadav, Nitish (2018) Karl Marx-Historical Materialism. University of Delhi. 